\title{
Empire State College: The Development Of Online Learning
}

Patricia Lefor

Meg Benke

Evelyn Ting

\begin{abstract}
Empire State College was founded in 1971 to meet the needs of adult and other nontraditional student populations in the state of New York. Its initial delivery model was individualized instruction with a student working with a full-time faculty member to develop a unique plan of study and learning contracts to support that plan. By 1979, the College established the Center for Distance Learning, which developed and still offers structured, print-based courses to students with no requirement for onsite meetings. It began to experiment with computer-supported learning activities in the late 1980s, employing professional staff to support the exploration of technology and to provide assistance to faculty in instructional design. However, it was not until 1994, with the formal creation of the Center for Learning and Technology, that the development of online courses and programs was systematically pursued. This article outlines the development of online programs since that time, emphasizing the issues and challenges faced by the institution in seeking to provide quality, cost-effective distance education.
\end{abstract}

\section{Introduction}

\section{Description of the institution}

Empire State College (ESC) was founded in 1971, under the leadership of Ernest Boyer, the Chancellor of the State University of New York (SUNY) at that time. Boyer recognized that, while the broad distribution of public colleges and universities in New York State provided geographic proximity for most of the residents of the state, SUNY did not meet the needs of those who could not take a full time course load, or could not attend regularly scheduled classes because of work, family and community commitments. SUNY Empire State College was founded with a mission of access and quality and with a goal of establishing new ways of teaching and learning. 
The three key barriers to access were defined as place, time, and curriculum. The problem of geography generated a plan to disperse instructional sites and, in so doing, to utilize other SUNY campuses and local communities as sources for such traditional academic needs as library access. The matter of time was addressed by establishing individually scheduled interactions between a student and a faculty member and enrollments that could begin any day of the year. The need to meet a variety of academic goals generated a broad, generic set of registered programs, unique in New York, within which individualized curricula could be created. It was recognized that, because of their other commitments, students at this College would likely require a longer period for degree completion and would, in the process, need useful academic credentials in the interim. This led to the offering of both 2 and 4 year undergraduate degrees. Subsequently, the College was approved to offer masters level degrees as well.

Consistent with the social issues that drove the College's development, the philosophy of the founders explicitly incorporated learning that could have occurred anywhere, not just in a lecture hall under the tutelage of a faculty member. To distinguish its faculty role from those found in more traditional colleges, Empire State College referred to faculty members as mentors.

ESC's development of print-based distance learning materials was initiated, in its current form, in 1979 when the College established the Center for Distance Learning (CDL), incorporating a number of the prior initiatives focused on the development of structured learning materials. CDL had a dual purpose in both serving its own matriculating students working entirely at a distance and students from centers and units across New York State, who were incorporating distance courses into their programs. The history of the College, including the development of its distance learning program, is discussed in some detail in The Promise Continues (Bonnabeau, 1996).

\section{Efforts made to convert programs delivered via print to online modes}

Throughout the 1980s, CDL generated about 2,000 enrollments a year in its print-based courses. By the late 1980s, the College began to explore ways to incorporate computer-based activities into its distance learning course offerings. The first attempt involved the addition of a text-based computer conferencing software called CAUCUS to existing print courses. Another initiative, begun in 1991 and discontinued in the spring of 1995, involved the use of televised lecture-based courses, using one-way video and two-way audio, offered at classrooms located at community colleges in New York State. These synchronous courses used the SUNY Network delivery system and were staffed with on-site academic assistance. The intended audience for the program, known as SUNY by Satellite, was community college graduates interested in pursuing bachelor's level programs in business.

International Review of Research in Open and Distance Learning 
As the potential of asynchronous, computer-based instruction grew, the College's efforts to expand into this area were hampered by its small size and resource base. By 1994, the potential of technology in instruction had exploded onto the higher education scene. After 15 years of experience in print-based distance learning, Empire State College began to work with others in the State University of New York to initiate online educational delivery. With substantial funding from the Sloan Foundation, and in a collaboration known as the SUNY Learning Network (SLN), a number of institutions began to establish new, or convert existing, courses for web-based distance learning. The initial planning and implementation of this project were among the responsibilities assigned to ESC's Center for Learning and Technology. The context for the SLN project will be discussed below.

\section{Problems and/or issues encountered}

The development of asynchronous learning was attractive to ESC. It provided opportunities for students to work on their own schedule and to interact, by computer, with each other and with a faculty member. The College developed more computer-based courses in the initial years of the SUNY Learning Network than did other SUNY partners, and, under the aegis of the SLN, began to build a full baccalaureate business program available on the WWW. However, the majority of the faculty at the College, who work with students in the geographically distributed centers and units, did not embrace or participate actively in the development of online courses and programs. This initially resulted in low enrollments in the newly developed courses, at centers and units as well as on the part of CDL matriculants. And since the Center for Distance Learning was functioning at this time in the College's history as a self-contained program, there were internal issues in regard to resource allocations for the project, to mission and audience, and to internal competition for students. By 1997-1998, CDL had developed a successful strategy for marketing these courses to its own matriculants, on the ESC web site [http://www.esc.edu/OnlineDegrees] as well as through the SUNY Learning Network [http://sln.suny.edu/sln].

\section{Institutional responses to these problems and issues}

While devoting considerable energy and the resources of the Center for Learning and Technology to the SUNY Learning Network and CDL's participation in it, the College undertook two other initiatives in order to demonstrate the power of technology in all aspects of its programs. One of these initiatives was implementing a technology infrastructure in support of the distributed model characteristic of the College, including the widespread distribution of PC workstations and the development of internal applications such as e-mail, online academic records preparation and processing, and online resources for the use

International Review of Research in Open and Distance Learning 
of students and faculty across the College. The other was an internal planning project, cutting across the various programs of the College, focused on the question of distance learning at ESC.

\section{Overview of the case}

This case covers briefly the internal and external factors that influenced the transition from a print-based distance learning program to one combining both print and online courses. The main thrust of this article is on the involvement of ESC's faculty and professional staff in this development, with special attention to the role of the College's Center for Learning and Technology in the SUNY Learning Network.

\section{Structure, Culture and Processes Unique to Em- pire State College}

Empire State College is an institution that prides itself on presenting an alternative for adult learners. It has sustained its commitment to the initial innovation of individualizing academic programs and the content of particular studies with individual students during its 30 year history. The distributed and decentralized structure that supports mentoring in centers and units across the state is paralleled by a more structured set of programs offered, usually by termbased programs, and coordinated centrally from the College's offices in Saratoga Springs. The Center for Distance Learning is, as noted above, one of the structured programs developed and coordinated at the College's administrative site.

Over much of the life of distance learning at ESC, full degree programs were available in only two of the generic program areas (Business, Management and Economics; Community and Human Services) and in Interdisciplinary Studies. Students enrolled in small, print-based courses, having frequent contact with their instructors by phone and mail. Though not meeting mentors face-toface, the students enrolled through the Center for Distance Learning have the institutional association of a mentor, who serves as an academic advisor and who provides support in addition to that given by the course instructor.

In contrast, most of the College's students were connected to a specific geographic location, enrolling in a center, which might have 20 or more faculty members, or an affiliated unit, which could have as few as 2 mentors. Learning opportunities were necessarily rooted in the actual resources available to the local faculty. In spite of the preference for one-on-one learning, the College has always employed a large number of instructional approaches. Assisting students to adapt to the learning approaches of the College, and developing individual-

International Review of Research in Open and Distance Learning 
ized degree programs were heavy, front-loaded faculty responsibilities. As the proportion of part-time students increased, the numbers of individuals assigned to a primary mentor grew accordingly. This additional work, and the lack of growth of state support for public education, encouraged the use of structured learning options, which could replace some of the individual mentoring.

The co-existence, peaceful and otherwise, of these two quite different program approaches (and their variations), is one of the most unique features of ESC, leading to multiple structures, processes, and goals. The College's administrative culture has been based on concepts drawn from strategic management; particularly, it has focused on being open and responsive to opportunities that fall within the overall mission and the directions set to realize that mission. In attempting to be agile and entrepreneurial, planning and implementation processes are incremental, using new initiatives as prototypes or pilot activities for wider dissemination after a successful trial period. In response to the public disinvestment in higher education experienced throughout its history, ESC has consistently explored and developed self-supporting programs that could bring additional resources for reinvestment to the institution. These newer programs are based on more structured models of instructional delivery and on distance learning.

\section{Extra-institutional and Environmental Factors Sig- nificant to Empire State College}

Empire State College began its history with a unique mission and target audience. Over the 30 years of that history, there has been a sharp decline in the public investment in higher education, particularly though not exclusively in New York State. There has also been increasing competition for adult students in higher education, including on the part of colleges and universities that had not recruited this population in the 1970s. Many of those recruitment efforts have used the language that was once unique to ESC in reaching out to new audiences. At the same time, there has been a rapid development of technology which can and does support a variety of educational initiatives. There are also workforce development concerns that stress the importance of life-long learning. The volatile mix of these factors presents both opportunities and threats to the College, and has focused its planning and development efforts in the area of technology based academic and student support services and on increasing online program development. 


\section{Influential Institutional Environmental Demands}

With the creation of the National Research and Education Network, authorized by the Federal High Performance Computing Act in 1991, the development of a public communications network became the focus of the New York State Forum for Information Resource Management. Their report, published in December 1992, had as its first recommendation the creation of an integrated network for education (New York State Forum, 1992). By 1994, the Office of Educational Technology, part of SUNY system administration, had outlined a five-year plan which included the goal of networking its campuses and providing access to students in every part of the state (State University of New York, 1994). In 1994, a funding grant from the Alfred P. Sloan Foundation's Learning Outside the Classroom Program began the work which was the basis for the SUNY Learning Network [http://www.sloan.org/programs/edu_asynchronous.htm]. In January 1995, a group of SUNY Presidents published a report, outlining twelve objectives addressing the implementation of distance learning (State University of New York, 1995). James W. Hall, founding president of ESC, was serving as Vice Chancellor for Educational Technology during this period.

The SUNY institutions participating in the Learning Network collaborated to create a development and delivery platform, but single site service systems for cross registration between the participating institutions have not been established. The participating institutions continue to register primarily their own students and to function independently, duplicating academic programs and courses. This independence means that, while SUNY is one of the largest distance learning providers in the country, expertise and reputation exist primarily within the individual campuses.

Internal to ESC, strong faculty interest in distance learning has developed only in the last two years. While there were a few early starters in the 1980s, mistrust of distance or technology delivered education had evolved as the norm. Additional resources, such as computers and professional development funds, facilitated the recruitment of faculty for course development in the early years. Faculty had to be encouraged by administrators, by distance learning faculty colleagues, and occasionally by the students themselves to consider registering students in WWW courses. While some faculty members remain suspicious of structured WWW courses, there has been a marked increase of interest in the potential of these methods for design of instruction in the last 2 years. Mistrust of online course development originated from the budget climate in New York State during the late 1980s through the mid 1990s and the resulting competition for resources within the college. Nonetheless, center and particularly unit mentors made use of CDL print courses as institutional resources for students. That usage has extended to online courses.

A high investment was made by instructional technology and course development faculty to develop the early online programs. These programs were ini-

International Review of Research in Open and Distance Learning 
tially supported by a combination of external funding and decisions to use the print-based program resources to sustain early enrollments. The College made a deliberate decision to focus development within areas that represented significant student demand in both print-based courses and mentored programs, initially Business, Management and Economics, and now Community and $\mathrm{Hu}-$ man Services. This is in contrast to many institutions that based development of online courses on faculty interests, resulting in a scattering of courses from many different areas of study rather than in programs delivered entirely online.

\section{Critical Incidents in the Conversion to Delivery of Online Programs}

The College's prior use of two technology-mediated deliveries influenced its webbased developments. First, a positive culture was cultivated by the work of innovating faculty who began using text-based computer conferencing as a distance delivery mode as early as 1986 . Advantages and characteristics of this mode were discussed and documented in publications which created, at least in some parts of the College, an interest in the pedagogical advantages of student-to-student interaction at a distance, a feature not easily incorporated into the center and unit based programs (Eastmond, 1995; Fey, 1992; Marantz \& England, 1993; Roberts, 1987). These studies, particularly Eastmond's dissertation research, which culminated in Alone But Together: Adult Distance Study through Computer Conferencing, confirmed the benefits of electronic networking in reducing the intellectual, and sometimes social, isolation of adult students studying independently. The Fey study, particularly, confirmed that networked learning complemented the College's "traditional" mentor-student teaching model.

The SUNY by Satellite experience established a framework for collaborative program development, particularly with SUNY community colleges. The 1994 Sloan grant, noted above, was crucial to ESC's online course development. This grant provided funding for ESC and seven other SUNY institutions to develop both courses and an asynchronous learning network infrastructure. Grant funding established the project as a collaborative development within the SUNY system and funded Empire State College staff positions as the project team, giving the College's Center for Learning and Technology a unique status within the consortium. While this gave ESC's technology staff a significant role in the implementation of the SUNY Learning Network, it also led to confusion about their roles and responsibilities vis-á-vis the College. Table 1 summarizes enrollments, activities, and critical decisions in the college's implementation of online programs.

ESC's implementation of online programs has a direct relationship to its continuing print-based course offerings. As noted, the College has focused on developing online courses that allow students to pursue academic programs entirely

International Review of Research in Open and Distance Learning 
online. However, the CDL course catalog lists course titles for both print and online delivery. Courses that constitute core subject matter in the two online program areas are offered on a regular schedule in both delivery modes.

Table 1

\section{Empire State College development of online courses: Chronology of events and decisions}

\begin{tabular}{|c|c|c|c|}
\hline & $\begin{array}{l}\text { Timeline }^{*} \\
\text { and Growth }\end{array}$ & Events & Critical Decisions \\
\hline & $\begin{array}{l}1994-1995 \\
- \text { Planning } \\
1995-1996 \\
-6 \text { courses } \\
-65 \text { students }\end{array}$ & 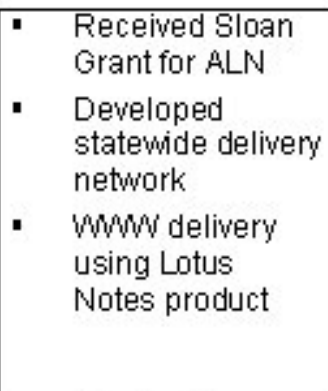 & $\begin{array}{l}\text { Terminate synchronous } \\
\text { video program } \\
\text { Collaborate with other } \\
\text { SUNY colleges } \\
\text { Assign ESC staff to } \\
\text { system-wide project } \\
\text { (network development, } \\
\text { faculty development, } \\
\text { course design, student } \\
\text { support) }\end{array}$ \\
\hline & $\begin{array}{l}1996-1997 \\
-18 \text { courses } \\
-191 \text { students } \\
1997-1998 \\
-38 \text { courses } \\
-515 \text { students }\end{array}$ & $\begin{array}{l}\text { Adopted Course } \\
\text { Management } \\
\text { System } \\
\text { Standardized } \\
\text { faculty } \\
\text { development } \\
\text { process } \\
\text { - Added student } \\
\text { help desk }\end{array}$ & $\begin{array}{ll}\text { - } & \text { Adopt uniform Course } \\
\text { Management template } \\
\text { - } \quad \text { Focus on replicable and } \\
\text { Scaleable processes } \\
\text { - } \quad \text { Integrate WWW courses } \\
\text { into college's distance } \\
\text { learning organization }\end{array}$ \\
\hline & $\begin{array}{l}1998-1999 \\
-81 \text { courses } \\
-859 \text { students } \\
1999-2000 \\
-127 \text { courses } \\
-1515 \text { students }\end{array}$ & $\begin{array}{l}\text { Created online } \\
\text { support services } \\
\text { ("Virtual Student } \\
\text { Center") }\end{array}$ & $\begin{array}{l}\text { - Reallocate staff from } \\
\text { System-wide project back } \\
\text { to ESC } \\
\text { - Focus on online student } \\
\text { services } \\
\text { - Expand degree programs }\end{array}$ \\
\hline
\end{tabular}

A critical decision made during the second year of the SLN project was to adopt a single standardized course management system and template. Figure 1 is an example of a course management template for a business course. Although use of a single course management system and template was of significant benefit to students enrolling in online courses, it was not always viewed positively by faculty at ESC or elsewhere, particularly among those who were interested in technology and in exploring software options. In its first year, the faculty involved in the SLN project were volunteers interested in technology. Grant 
funds permitted generous compensation including extra service payments, laptop computers, a 1 year development timeline for courses, and a stipend for software, training, and conference travel. By the second year, the project was expanding, and the demand for new course developers necessitated involvement of faculty who were less enthusiastic and knowledgeable about technology. With this second group of faculty the use of a single course management system and template was a benefit. To further support faculty less comfortable with technology, the CLT staff institutionalized a faculty development and decision process which emphasized text-based interactive assignments such as discussion, small group work, and self-assessments (multiple choice and true/false). Examples of these kinds of learning activities can be seen at [www.esc.edu/examples] - this is a password-protected site: User name: Faculty Guest; Password: guest. Development of more labor intensive course supplements such as graphics, simulations, and audio/video files were left to individual faculty members, rather than being supported by project staff.

Figure 1

\section{Example of Course Management Template}

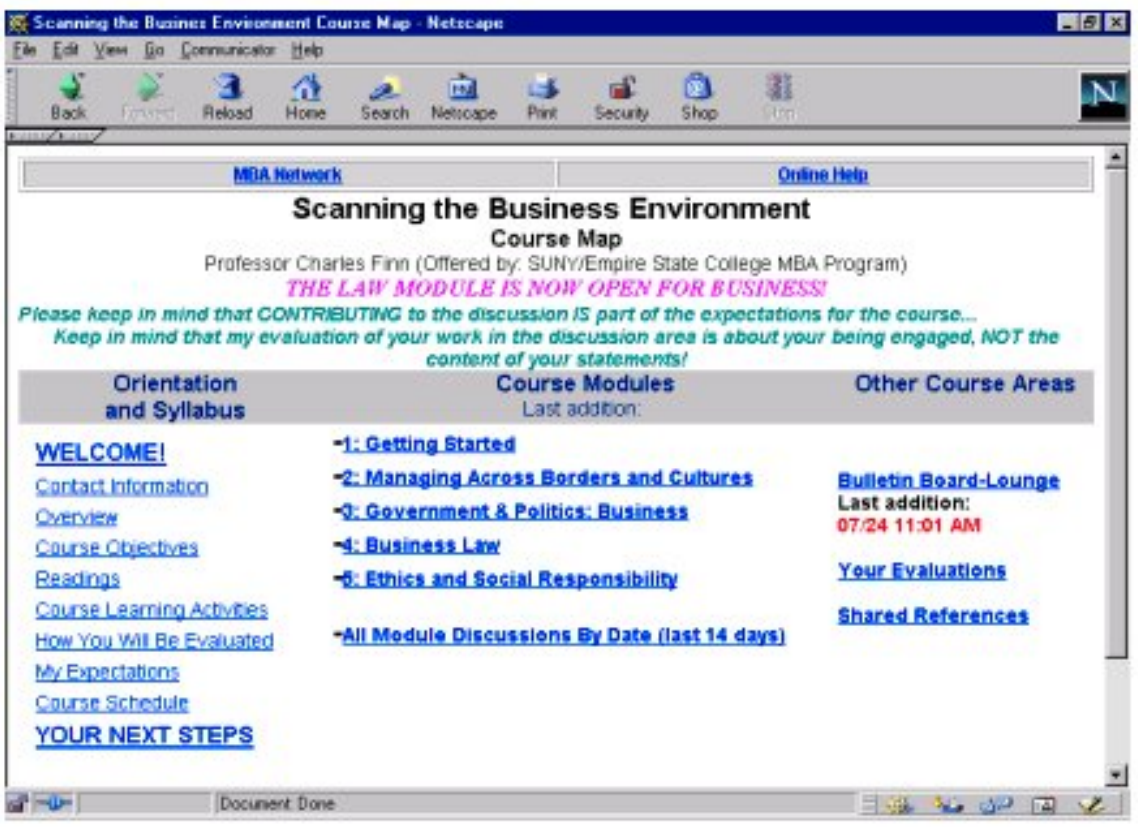

A corollary decision was made to concentrate time and effort on "replicable" and "scaleable" processes. The CLT staff automated a number of support functions such as creation of course files, security access to courses, and term course listings. While this was more time-consuming in the short run, the processes 
and tools have allowed the SUNY Learning Network to grow, during a 5 year period, from 4 courses and 50 students to 1,000 courses and 12,000 students [sln.suny.edu/sln]. During this initial phase of development, the College piloted online delivery of some services, including online registration and orientation, academic advising, technical help and librarian assistance.

A third critical decision, implemented during the expansion phase of the SLN (the academic years 1996-97 and 1997-98), was to assimilate the web-based courses into the College's distance learning operation, moving from special project status into full integration. Until that point, the management of course development and delivery systems had been parallel to, but primarily independent of, the College's print-based distance learning operation. Faculty development, instructional design practices, course review, materials ordering, initial student contacts, and even recruitment, marketing and orientation sessions were handled by the grant project team. In fall 1998, the College began full integration of online course development and delivery with its other distance learning program. The decision supported expansion of the web-based program, both in enrolling existing ESC students in online courses and marketing to new audiences. During the assimilation period, online faculty were included in tutor development activities and academic coordinators from the Center for Distance Learning took on oversight of course development. Management of course delivery was integrated with the core distance learning operations, a process facilitated by the college's implementation of a new administrative system.

During the 1998-1999 academic year, the College made the decision to reallocate the CLT staff from supporting system-wide distance learning to ESC projects. This decision reduced the College's influence on distance learning within the SUNY system. However, the reallocation made staff available for another key activity: development of online support services for students. While the College had a robust set of online course offerings, it had not focused on online student support services. Through the Virtual Student Center Project [www.esc.edu/student], the College began systematic development of these services online. While the college had always been adept in being able to provide support services at a distance via phone and mail, web-based technology permitted other institutions to leap frog from in-person to WWW services ahead of ESC.

In 1999, Empire State College decided to expand its degree offerings through programs in Community and Human services [www.esc.edu/onlinedegrees]. This decision responds to student interest, but also challenges online program development. In many ways, the target audience and faculty for this program resembles those of the Business, Management and Economics program 4 years ago: students are less likely to own computers and have Internet access, and faculty have not had much experience using technology. The College is using some of the same incentives used earlier to support development in this area of study.

International Review of Research in Open and Distance Learning 


\section{Intended and Unintended Consequences of Con- version Efforts}

The move to web-based delivery was motivated by three considerations. Primarily, the College was concerned about its ability to continue to compete in a distance learning environment that was moving to greater use of technology to support learners. At the same time, the College saw the potential for improving the quality of learning for students working at a distance by promoting greater interactivity with faculty and other students. Greater interactivity also had the potential to improve student satisfaction and retention as well. Finally, some faculty were also interested in the innovative aspects of technology assisted learning and in exploring the potential for improving student learning and faculty work.

Improvements to the learning/teaching system have been realized, but probably not to the extent we initially hoped. Retention rates for the web-based courses mirror the rates for the College's print courses, which range around 70 to $75 \%$ for advanced level business courses and around 60 to $65 \%$ for introductory business and general courses. Currently ESC is engaged in research focused on the introduction of its online program in Community and Human Services, which will explore such differences. Students in WWW courses are much more likely to complete on time, and generally seem to be satisfied with, the online courses. Results of student satisfaction surveys indicate that adult students value highly the interaction with the instructor as a contributor to the learning experience. Students also apparently find benefit in their interactions with other students; regression analysis of the end of term survey data show that students rate highly the opportunity to share different perspectives on course issues and to provide mutual support (Jiang \& Ting, 1998; Richardson, Tunwall \& Carnevale, 2000).

An unintended consequence has been the impact on the faculty who have participated in online course development efforts. Adjunct faculty teaching in both the print and online courses greatly improved the currency of resources and access to resources for students. Course designers have begun to incorporate publisher resources and focused web sites into both print and online courses. In addition, a number of faculty from various parts of the college began to work collaboratively in course development teams. These faculty speak enthusiastically about the impact of solving teaching problems with their colleagues and transferring the successful methods they have developed in online teaching to other modes of delivery.

Faculty have also improved responsiveness to students and have greater access to resources. In the initial years of teaching online, faculty often over-taught and then raised concerns about increased workload. They created course designs and response systems that resulted in the need to individualize all responses to students. Attention was given to this problem by the CLT staff and the CDL

International Review of Research in Open and Distance Learning 
faculty who coordinated course development to help faculty to create designs which allowed for automatic feedback or student-to-student interaction, not always requiring individualized responses.

The Center for Distance Learning has deliberately moved away from operational systems that rely on mail, fax and phone for students and faculty. All faculty and adjuncts are expected to have access to the WWW, and the Center has designed systems to facilitate reporting on student progress. Within the last several years, student service systems have been designed to allow students to apply, register, check on their status and connect with other students on the WWW. As expected, students in both online and print courses quickly began to use these services to do their business with the College. Over $50 \%$ of distance learning students now register for courses, whether print or online, on the WWW.

Recruitment goals for online courses included both internal marketing to the existing students of the College and attempts to reach out to new audiences. Analysis of inquiries and registrations indicate that new students are attracted to online courses. They are slightly younger than students registering for print courses (the average age is the 30s rather than 40s), more often male, and generally employed. Many students are attracted to ESC's programs because of interest in individualizing their study and getting credit for prior learning as part of the degree program. Unlike these general goals, students pursuing programs online report their primary interest is in completing degrees or courses

entirely on the WWW. Online course enrollments represent only ten percent of CDL's overall annual enrollment. Internal marketing has not been as effective as anticipated, with less than a third of the online enrollments coming from other centers and units of the College. CDL had projected that online enrollments would have grown to half of its delivery within 5 years of initial development. While online enrollments are growing, enrollment in print course also continues to grow.

\section{Implications of this Experience}

Debates relating to the value of technology or distance supported delivery are evident in almost all higher education institutions. Those most centrally involved in ESC's development of online distance learning opportunities recognized that this debate was only telling if it centered on reinforcing the institution's core values of student-centered approaches to education. The College has developed its online programs in response to the academic interests of its existing student populations. It worked for several years to prioritize a standardized approach to web-based delivery of both courses and related student services and to create an advising culture which supported the value of learning through this delivery approach. The development of programs rather than individual courses resulted 
in a more cohesive marketing message, which encourages students to return to a program. The development of online services for students at a distance is closely aligned with the delivery of courses. The ability to grow and sustain enrollment requires attention to the needs of the adult student and to their interactions with the institution.

The process of establishing policies and procedures to support viable online programs was accomplished in the early stages of the SLN project. They were applied and amplified, within CDL's planning processes, once the project was integrated fully into its operations. As a result, a number of potentially controversial issues were resolved at the pilot stage.

The marketing of new online teaching and learning options has been facilitated by the parallel development of technology resources for the entire ESC student and faculty. In fact, the Virtual Student Center, though conceptualized as a support for distance learning students, has proven to be a more general resource, used by both students and faculty throughout the College.

The College has embarked on a research and evaluation study, related to the implementation of its online Community and Human Services program, that will address a number of the questions posed by the institutional data presented in this article.

\section{Conclusion}

If examined from the perspective of program development, Empire State College, as well as other institutions engaged in developing online academic programs, required an extensive investment to actually implement such programs. The College's development was subsidized by grant funding, through the State University of New York. SUNY as a system has supported the expansion of online course development for interested members of the system. ESC's successes in this area would not have been possible had funding been restricted to the annual budget of the College.

In the 6 years since it introduced online web-based courses, the College has seen an increase in enrollment, though it has not reached a level that allows for reinvestment, much less the recovery of initial investment. Nonetheless, the College's focus on providing degree programs entirely online and the support services required by distance learners has allowed it to expand its initial mission of access and flexibility. Online course and program development has emerged from and reflected the substantial experience of the faculty in facilitating academic achievement for adult students and in increasing the experience of community among distance learners.

While the continued development of online programs at Empire State College

International Review of Research in Open and Distance Learning 
will require additional resources to expand both academic and other student support services, the initial investments in infrastructure and learning management systems has made ongoing development easier. The College has been able to adapt many of its technology developments and service supports to new applications, such as its online MBA program. The College's substantial experience in providing programs at a distance for adult learners has grown as a result of its efforts to include web-based online delivery as an option. Most recently, this experience has been the basis for addressing Federal government mandates in regard to providing educational services to people serving in the military.

The College's strategic planning reflects a continued emphasis on online programs as well as the full integration of online academic resources as a tool for teaching and learning. ESC has articulated a blended resource model in terms of delivery, including online and print-based courses, individual mentoring and tutoring, cross-registrations at other colleges and both local and college-wide group studies. The differences between distance learning and other forms of higher education have never been as extreme at Empire State College as in more traditional institutions in the United States.

The online program began in 1995-1996 with 6 courses delivered to 65 students. Online enrollments in 1999-2000, the fifth academic year during which online courses were offered, included 1,515 students in 127 courses. The proof of concept of the College's focus on developing online programs, learning resources and student support services will be the result of continuing efforts to increase scale. 


\section{References}

Bonnabeau, R. (1996). The promise continues: Empire State College, the first twenty-five years. Virginia Beach, VA: Donning Company Publishers.

Eastmond, D.V. (1995). Alone but together: Adult distance study through computer conferencing. Cresskill, NJ: Hampton Press.

Fey, M.H. (1992). Freeing voices: Literacy through computer conferencing and feminist collaboration. Unpublished doctoral dissertation, University of Rochester.

Jiang, M. \& Ting, E. (1998, April). Course design, instruction, and students' online behaviors: A study of instructional variables and students' perceptions of online learning. Paper presented at the American Educational Research Association, San Diego, CA.

Marantz, B. \& England, R.J. (1993). Can CMC teach teacher training? Educational Media International, 30(2), 74-77.

New York State Forum for Information Resource Management, (1992, December). Telecommunications: A vital infrastructure for the "New" New York. (Rockefeller Institute of Government, Albany, NY 12203-1003).

Richardson, J., Tunwall, C., \& Carnevale, C., (2000, June). The affordances and constraints of asynchronous learning networks: Looking at interaction in an online environment. Presented at Ed-Media 2000 World Conference, Montreal, Canada.

Roberts, L. (1987, May). The electronic seminar: Distance education by computer conferencing. Paper presented at the annual conference on NonTraditional and Interdisciplinary Programs, Fairfax, VA. (ERIC Document Reproduction Service No. ED 291 358).

State University of New York, (1994, December). Educational Technology Initiative. Albany: State University of New York, Office of University Relations for the Office of Educational Technology.

State University of New York, (1995, January). Distance learning: The Presidents' Task Force Report. Albany: State University of New York, Office of Educational Technology, President's Task Force.

SUNY Empire State College, (1997, July). The Report of the Distance Learning Task Force. [internal document]. 


\section{Citation Format}

Lefor, Patricia, Benke, Meg \& Ting, Evelyn (January 2001) Empire State College: The Development Of Online Learning. International Review of Research in Open and Distance

Learning: 1, 2. http://www.icaap.org/iuicode?149.1.2.5 